\title{
Organic Fertilizers improve the Growth, Seed Quality and Yield of newly Released Soybean (Glycine max (L.) Merrill) Varieties in the Tropics
}

\author{
Tobechi Onyenali, \\ Victor Olowe*, \\ Thomas Fabunmi \\ and Soretire Adeniyi \\ Federal University of \\ Agriculture Abeokuta \\ (FUNAAB)
}

Corresponding author: owebaba@yahoo.com

Keywords:

growth, oil content, protein content, seed yield, yield attributes

\begin{abstract}
Soybean (Glycine max (L.) Merrill) yield in tropical Africa remains below 1t/ha partly because most growers rarely use beneficial organic soil amendments on degraded tropical soils. Therefore, filed trials were conducted during the late cropping seasons (July-Nov.) of 2015 and 2016 on the organic research plots of the Institute of Food Security, Environmental Resources and Agricultural Research, Nigeria $\left(7^{\circ} 23^{\prime} \mathrm{N}, 3^{\circ} 39^{\prime} \mathrm{E}\right.$, altitude $139 \mathrm{~m}$ above sea level). The trials evaluated the agronomic response of five recently released soybean varieties (TGx 1448-2E, TGx 1440-1E, TGx 1740-2F, TGx 1987-62F and TGx 1835-10E) to the application of three commercial organic fertilizers (Aleshinloye Grade B, Organo-Farm and Gateway) and a control. The trials were laid out in randomized complete block design $(R C B D)$ in a $5 \times 4$ factorial arrangement and replicated three times. Data were collected on growth parameters, yield and yield attributes, and seed quality. Significant $(P<0.05 ;$ F-Test) varietal difference was recorded for aboveground plant weight, grain filling period, height at physiological maturity, number and weight of pods per plant, number of branches and seed yield, and quality in both years. Application of organic fertilizers significantly $(P<0.05 ; F$-Test $)$ increased aboveground plant weight, number of branches, pods, weight of seeds per plant, seed yield and quality in both years relative to the control treatment, except oil content and seed yield in 2016. The three organic fertilizers appear appropriate for soybean cultivation since soybeans grown on treated plots produced seed yield above 1/ton in both contrasting years of experimentation.
\end{abstract}

\section{Introduction}

Soybean (Glycine $\max (\mathrm{L}$.$) Merrill) is mainly grown for its seed that contains 18-25 \%$ oil and $30-50 \%$ protein required for human and animal nutrition (Manna, 2014). At present in tropical Africa, the average seed yield of soybean is below $1 \mathrm{t} / \mathrm{ha}$ as against the world average of $2.7 \mathrm{t} / \mathrm{ha}$ (FAO, 2016). General low yields of food crops in the tropics have been attributed to low soil fertility status, weed infestation, rising cost of agrochemicals, low purchasing power of resource-constrained farmers, lack of improved crop varieties, lack of access to necessary inputs, poor management practices among others (Affholder et al. 2013; Zerihun and Haile, 2017). The use of low input technology such as organic fertilizers will go a long way in ameliorating some of the challenges farmers face in the tropics. According to Chen (2006), all the required nutrients by plant must be present in the soil in balanced quantities and forms for the plant's optimal growth. Organic soil amendments have been reported to improve the physical and chemical, and biological properties of the soil through the improvement of soil aeration, soil carbon exchange capacity (CEC), water holding capacity, slow mineralization of organic materials (Yan et al. 2007; Zhong et al. 2010; Gautam and Pathak, 2014). Unfortunately, fewer efforts have been made thus far to explore the potential of the use of only organic fertilizers to boost the productivity of soybeans in the tropics. Some of the documented efforts are from Indonesia (Abidin and Sutrisno 2015, Kuntyastuti et al. 2018), Pakistan (Javaid and Mahmood 2010), Egypt (Mekki and 
Ahmed 2005), Nigeria (Olowe et al. 2014), India (Aher et al. 2015). However, most of these studies were limited to grain yield and yield attributes, not addressing seed quality as affected by the applied organic fertilizers. Therefore, our study was carried out to evaluate the effect of organic fertilizer application, on growth, yield, yield attributes and quality of soybeans in the tropics.

\section{Materials and Methods}

The field experiments were carried out on the organic research plots of the Institute of Food Security, Environmental Resources and Agricultural Research, Nigeria $\left(7^{\circ} 23^{\prime} \mathrm{N}, 3^{\circ} 39^{\prime} \mathrm{E}\right.$, altitude $139 \mathrm{~m}$ above sea level) during the late cropping seasons of 2015 and 2016 on a sandy loam soil. During the period of experimentation, a total rainfall of 435.8 and $519.1 \mathrm{~mm}$ was recorded in 2015 and 2016, respectively. Based on the results obtained from soil analysis, the soils of the experimental sites were loamy sand in texture and contained 0.11 and $0.12 \%$ total nitrogen, 1.17 and $1.19 \%$ total organic carbon, available $\mathrm{P}$ 16.42 and $48.69 \mathrm{mg} / \mathrm{kg}, 0.28$ and $0.91 \mathrm{~mol} / \mathrm{kg}$ exchangeable potassium with $\mathrm{pH}$ of 6.1 and 6.2 in 2015 and 2016, respectively. The experimental design was randomized complete design in a $5 \times 4$ factorial arrangement and replicated three times. The factors were varieties: TGx 1448-2E (late maturing), TGx 1440-1E (Late maturing), TGx 1740-2F (Early maturing), TGx 1987-62F (Early maturing) and TGx 1835-10E (Early maturing) and organic fertilizers: Alehinloye Grade B $(0.58$ and $0.56 \% \mathrm{~N}$; abattoir waste based), Organo farm (1.58 and $1.67 \% \mathrm{~N}$; brewery waste based) and Gateway $(0.50$ and $0.50 \% \mathrm{~N}$; animal dung and wood ash based) in 2015 and 2016, respectively. Sowing was done on the experimental plots that consisted of six rows measuring $4 \mathrm{~m} \times 3 \mathrm{~m}\left(12 \mathrm{~m}^{2}\right)$ at $60 \mathrm{~cm} \times 5 \mathrm{~cm}$ giving a total plant population of 333,000 plants per ha. Sowing was done on July 15, 2015 and July 13, 2016. Organic fertilizers were applied at three weeks after sowing (WAS) immediately after the first weeding. The second hoe weeding was done at 6WAS. Thereafter, five plants were randomly selected and tagged at 5WAS from the net plot for plant height and yield attribute measurement on plot basis. Data were collected on plant height at physiological maturity (R7), grain filling period (GFP), and above ground plant weight. At harvest, data on yield attributes (number of branches per plant, number and weight of seeds and pods per plant were collected on five randomly selected plants from each plot and total plot yield was determined. The oil and protein content of seeds were determined using Soxhelt extraction and Kjeldahl block digestion and steam distillation, respectively (Egan et al. 1981). All data collected were subjected to analysis of variance (ANOVA) to test the main and interaction effects and where the effects were statistically significant $(P<0.05, F$-test $)$, treatment means were separated using the least significant difference(LSD) method.

\section{Results}

The five test varieties were significantly different $(P<0.05 ; F$ - test $)$ from each other for above ground plant weight, grain filling period, number of branches per plant and height at physiological maturity in 2015 and 2016. Similarly, application of Aleshinloye Grade B and Organo farm organic fertilizers significantly $(P<0.05)$ increased aboveground plant weight and number of branches per plant relative to the control. However, the organic fertilizer application had no effect on grain filing period and height at physiological maturity. The Variety $\times$ Fertilizer application effect on the measured growth parameters was not significant on the varieties in both years (Table 1). Pod number and weight per plant was significantly $(P<0.05 ; F$ - test $)$ affected by varietal effect and organic fertilizer application in both years, except the effect of organic fertilizer on pod weight in 2016. Application of Aleshinloye significantly $(P<0.05)$ enhanced seed weight of soybeans compared to other organic fertilizers and control. Variety 
and organic fertilizers had no effect on seed number per plant. Variety $\times$ Fertilizer Application effect was not significant on any of the measured yield attributes in both years (Table 2). The main and interaction effects significantly $(P<0.05 ; F$ - test) affected seed yield and quality in both years, except fertilizer

Table 1. Effect of organic fertilizer application on aboveground plant weight (ABGPWT), Grain filling Period (GFP), height at physiological maturity (HTR7) and number of branches per plant (NBR) of soybean varieties, 2015 and 2016

\begin{tabular}{|c|c|c|c|c|c|c|c|c|}
\hline \multirow[t]{2}{*}{ Treatment } & \multicolumn{4}{|l|}{2015} & \multicolumn{4}{|l|}{2016} \\
\hline & $\begin{array}{l}\text { ABGPWT } \\
\text { (g) }\end{array}$ & GFP & $\begin{array}{l}\text { HTR7 } \\
(\mathrm{cm})\end{array}$ & NBR & $\begin{array}{l}\text { ABGPWT } \\
(\mathrm{g})\end{array}$ & GFP & $\begin{array}{l}\text { HTR7 } \\
(\mathrm{cm})\end{array}$ & NBR \\
\hline \multicolumn{9}{|l|}{ Variety (V) } \\
\hline TGx 144-2E & 24.9 & 15.1 & 57.6 & 4.6 & 34.5 & 16.3 & 69.5 & 4.3 \\
\hline TGx 1440-2E & 27.4 & 17.8 & 56.9 & 5.8 & 35.7 & 14.9 & 75.2 & 5.0 \\
\hline TGx 1740-2F & 26.9 & 16.8 & 58.9 & 5.5 & 26.5 & 13.1 & 76.5 & 4.5 \\
\hline TGx 1987-62F & 18.3 & 14.5 & 50.1 & 3.5 & 21.9 & 13.8 & 66.9 & 3.5 \\
\hline TGx 1835-10E & 9.0 & 12.3 & 44.7 & 2.6 & 18.3 & 16.9 & 58.3 & 2.6 \\
\hline $\operatorname{LSD}(5 \%)$ & 6.71 & 0.62 & 5.78 & 1.24 & 11.36 & 2.07 & 7.61 & 1.32 \\
\hline \multicolumn{9}{|c|}{ Organic fertilizer (F) } \\
\hline Control & 14.1 & 15.3 & 67.9 & 2.9 & 16.6 & 15.6 & 67.9 & 2.6 \\
\hline Aleshiloye B & 28.7 & 15.6 & 71.1 & 5.4 & 35.6 & 15.5 & 71.1 & 4.1 \\
\hline Organo Farm & 23.9 & 14.8 & 69.9 & 5.2 & 33.9 & 14.5 & 69.9 & 4.9 \\
\hline Gateway & 18.5 & 15.5 & 68.1 & 4.0 & 23.4 & 14.4 & 68.0 & 4.3 \\
\hline LSD (5\%) & 6.00 & ns & ns & 1.11 & 10.16 & ns & ns & 1.18 \\
\hline $\mathrm{V} \times \mathrm{F}$ & ns & ns & ns & ns & ns & ns & ns & ns \\
\hline
\end{tabular}

ns - not significant

Table 2. Effect of organic fertilizer application on some yield attributes of soybeans, 2015 and 2016

\begin{tabular}{|c|c|c|c|c|c|c|c|c|}
\hline \multirow[t]{2}{*}{ Treatment } & \multicolumn{4}{|l|}{2015} & \multicolumn{4}{|l|}{2016} \\
\hline & PODN & $\begin{array}{c}\text { PODW } \\
\text { (g) }\end{array}$ & NSD & $\begin{array}{c}\text { WTSD } \\
\text { (g) }\end{array}$ & PODN & $\begin{array}{c}\text { PODW } \\
(\mathrm{g})\end{array}$ & NSD & $\begin{array}{c}\text { WTSD } \\
\quad(\mathrm{g})\end{array}$ \\
\hline \multicolumn{9}{|l|}{ Variety (V) } \\
\hline TGx 144-2E & 53.1 & 19.0 & 83.1 & 9.9 & 59.2 & 23.8 & 92.9 & 11.4 \\
\hline TGx 1440-2E & 65.7 & 25.0 & 85.0 & 13.2 & 55.2 & 24.5 & 83.4 & 10.9 \\
\hline TGx 1740-2F & 59.6 & 19.8 & 97.4 & 10.8 & 49.9 & 17.5 & 83.3 & 9.9 \\
\hline TGx 1987-62F & 36.4 & 13.2 & 76.4 & 9.4 & 33.1 & 11.5 & 76.9 & 8.2 \\
\hline TGx 1835-10E & 20.4 & 8.1 & 44.0 & 8.6 & 20.3 & 8.9 & 43.9 & 9.3 \\
\hline $\operatorname{LSD}(5 \%)$ & 17.43 & 8.19 & $\mathrm{~ns}$ & ns & 15.99 & 8.76 & ns & ns \\
\hline \multicolumn{9}{|c|}{ Organic fertilizer $(\mathrm{F})$} \\
\hline Control & 33.8 & 10.4 & 61.8 & 6.5 & 31.2 & 12.6 & 59.2 & 7.3 \\
\hline Aleshiloye B & 61.4 & 21.6 & 90.8 & 16.2 & 58.3 & 20.3 & 89.9 & 14.4 \\
\hline Organo Farm & 47.9 & 21.7 & 92.9 & 10.6 & 44.1 & 21.3 & 89.8 & 9.3 \\
\hline Gateway & 45.1 & 14.4 & 63.8 & 8.3 & 40.1 & 14.7 & 65.4 & 8.8 \\
\hline LSD (5\%) & 15.59 & 7.33 & ns & 4.03 & 14.30 & ns & ns & 4.30 \\
\hline $\mathrm{V} \times \mathrm{F}$ & ns & ns & ns & ns & ns & ns & ns & ns \\
\hline
\end{tabular}

ns - not significant, PODN - number of pods per plant, PODW - weight of pods per plant, NSD - number of seeds per plant, WTSD - weight of seeds per plant 
application and $\mathrm{V} \times \mathrm{F}$ effect on seed yield in 2016. Soybean plants that were grown on plots treated with Gateway fertilizer recorded the highest values for protein and oil content (significant at $P<0.05$ ) relative to soybean plants grown on other treated plots and control plots (Table 3).

Table 3. Effect of organic fertilizer application on seed yield and quality of soybean varieties, 2015 and 2016

\begin{tabular}{|c|c|c|c|c|c|c|}
\hline \multirow[t]{2}{*}{ Treatment } & \multicolumn{3}{|l|}{2015} & \multicolumn{3}{|l|}{2016} \\
\hline & $\begin{array}{l}\text { Seed } \\
\text { yield } \\
(\mathrm{kg} / \mathrm{ha})\end{array}$ & $\begin{array}{l}\text { Protein } \\
\text { content } \\
(\%)\end{array}$ & $\begin{array}{l}\text { Oil } \\
\text { content } \\
(\%)\end{array}$ & $\begin{array}{l}\text { Seed } \\
\text { yield } \\
(\mathrm{kg} / \mathrm{ha})\end{array}$ & $\begin{array}{l}\text { Protein } \\
\text { content } \\
(\%)\end{array}$ & $\begin{array}{l}\text { Oil } \\
\text { content } \\
(\%)\end{array}$ \\
\hline \multicolumn{7}{|l|}{ Variety (V) } \\
\hline TGx 144-2E & 1518.2 & 36.1 & 16.4 & 1833.3 & 35.5 & 16.9 \\
\hline TGx 1440-2E & 1824.8 & 36.1 & 17.4 & 1805.6 & 36.4 & 17.4 \\
\hline TGx 1740-2F & 1792.9 & 37.0 & 17.1 & 1715.3 & 36.1 & 17.3 \\
\hline TGx 1987-62F & 1015.3 & 36.8 & 17.4 & 1638.9 & 37.3 & 17.4 \\
\hline TGx 1835-10E & 547.3 & 37.2 & 17.4 & 1131.9 & 35.3 & 16.9 \\
\hline $\operatorname{LSD}(5 \%)$ & 314.89 & 0.24 & 0.03 & 365.08 & 0.22 & 0.32 \\
\hline \multicolumn{7}{|c|}{ Organic fertilizer $(\mathrm{F})$} \\
\hline Control & 997.9 & 35.1 & 16.5 & 1444.5 & 35.9 & 16.9 \\
\hline Aleshiloye B & 1595.7 & 36.9 & 17.6 & 1577.8 & 36.2 & 17.3 \\
\hline Organo Farm & 1446.6 & 37.2 & 17.0 & 1794.4 & 36.6 & 17.1 \\
\hline Gateway & 1318.7 & 37.4 & 17.6 & 1683.3 & 37.8 & 17.4 \\
\hline LSD (5\%) & 281.65 & 0.22 & 0.02 & ns & 0.19 & 0.28 \\
\hline $\mathrm{V} \times \mathrm{F}$ & $* *$ & $* *$ & $* *$ & ns & $* *$ & $* *$ \\
\hline
\end{tabular}

ns - not significant, ${ }^{* *}$ significant at $1 \%$ probability level

\section{Discussion}

The huge potential of organic soybean production had in the forest savanna transition zone of the humid tropics has been established (Olowe and Adebimpe; Olowe et al. 2014). Varying responses to organic fertilizer application were observed in the five tested soybean varieties. TGx 1440-1E, a late maturing variety, was the most vigorous variety and it produced significantly $(\mathrm{P}<005)$ higher above ground plant weight, pod number and weight than the two early maturing varieties (TGx 1987-62F and TGx 1835$10 \mathrm{E}$ ) in both years. However, it was on par with TGx 1448-2E (check and late maturing) and TGx 1740$2 \mathrm{~F}$, an early maturing variety, for aboveground plant weight, height at physiological maturity and number of branches per plant. Although, It was observed that neither plant height at physiological maturity or length on grain filling period directly resulted in greater plot seed yield even in the more favourable 2016 growing season. This agrees with the report of Board (2002). The two late varieties recorded longer grain filling period than the early maturing varieties and consequently significantly $(\mathrm{P}<0.05)$ higher grain yields than TGx 1987-62F and TGx 1835-10E in both years, except TGx 1835$10 \mathrm{E}$ in 2016 . The yield performance of the tested varieties compared very well with their potential (1.1 $2.7 \mathrm{t} / \mathrm{ha}$ ) in the traditional growing regions especially during the wetter 2016 (Asafo-Adeji and Adekunle, 2001). The varieties also contained comparable amounts of oil and protein. Application of the three commercial organic fertilizers, especially Aleshinloye Grade B and Organo Farm resulted in 
significantly $(\mathrm{P}<0.05$; F-test $)$ higher above ground plant weight and number of branches in both years relative to the control. Enhanced growth could be attributed to provision of macro and micro nutrients required for vegetative growth by the manure. Significant growth response to applied manure and compost had been reported by Yagoub et al. (2012) and Sutrisno (2017). On average, organic fertilizer application also significantly $(\mathrm{P}<0.05$; F-test $)$ increased pod number and weight, and weight of seeds per plant in both years, except pod weight in 2016. Enhanced development of soybeans on the treated plots could be due supply and availability of nutrients necessary for partitioning of assimilates to the various structural components of the plants. Similar results have been reported by Myint et al. (2009) and Devi et al. (2013). Application of Gateway organic fertilizer (animal dung and wood ash based) that contained comparatively high levels of micronutrients $(\mathrm{Zn}, \mathrm{Cu}, \mathrm{Fe}$ and $\mathrm{Mn}$ ) resulted in significantly $(P<.05)$ higher protein and oil content than the control and on par with the other two fertilizers. On average, the three fertilizers enhanced seed quality of soybeans relative to the control. It was concluded that application of organic fertilizers to soybeans is worthwhile venture that can boost its production in the tropics.

\section{References}

Affholder, F. Poeydebat, C. Corbeels, M. Scopel E. and Tittonell, P. (2013). The yield gap of major food crops in family agriculture in the tropics: Assessment and analysis through field surveys and modeling. Field Crop Research 143: 106-118.

Aher, S.B. Lakaria B.L. Kaleshananda, S. Singh, A.B. RAmana S, Ramesh K and Thakur J.K. (2015). Effect of organic farming practices on soil and performance of soybean (Glycine max under semiarid tropical conditions in Central India. Journal of Applied and Natural Sciences 7: 67-71.

Almaz, M.G., Halim, R.A and Martini, M.Y. 2017. Effect of combined application of poultry manure and inorganic fertilizer on yield and yield components of maize intercropped with soybean. Tropical Agricultural Science 40:173-184.

Asafo-Adeji B. and AdekunleA.A(2001). Characteristics of some released IITA soybean varieties and promising advanced breeding lines. IITAPublication. 10p.

Board, J.E. (2002). A regression model to predict soybean cultivar yield performance at late planting dates. Agronomy Journal 94: 483-492.

Chen, J. (2006). The combined use of chemical and organic fertilizer and or biofertilizer for crop growth and soil fertility. Taipei Food Fert. Technology Bulletin 17: 1-9.

Devi, K.N Singh T.B Athokpam, H.S. Singh, N.B and Samurailatpam D. (2013). Influence of inorganic, biological and organic manures on odulation and yield of soybean (Glycine max (L.) Merrill) and soil properties. Australian Journal of Crop Science 7:1407-1415.

Egan, H. Kick R.S. Sawyer R. (1981). Soxhlet extraction method. In Person's Chemical Analysis of Food. $8^{\text {th }}$ edn, pp507-547. London: Churchill Livingstone Publishers.

FAO (2016). Soybeans, yield (hectogram per hectare) for all countries. www.factfish.com/statistic /soybean $\% 2 \mathrm{C} \% 20$ yield.

Falodun, E.J., Ehigiator, J.O., Ogedegbe, S.A. 2015. Growth and yield response of soybeans (Glycine $\max (\mathrm{L}$.$) Merrill) to organic and inorganic fertilizer in Edo Rain forest of Nigeria. American$ Journal of Plant Sciences 6:3293-3297.

Gautam, S.S and Pathak N. (2014). Effect of organic fertilizers on soybean yield in Bundelkhand. Technofame 3: 84-87.

Javaid, A. and Mahmood N. (2010). Growth, nodulation and yield response of soybean to biofertilizers and organic manures. P.J. Bot.42: 863-871.

Khaim, S., Chowdhury, M.A., and Saha, B.K. 2013. Organic and Inorganic fertilization on the yield and quality of soybean. J. Bangladesh Agric. University 11:23-28.

Kuntyyastuti, H and Sutrisno, H.K. 2017. Effect of manure, phosphate solubilizing bacteria, and 
chemical fertilizer application on the growth and yield of soybean. Nusantara Biosciences 9:126132.

Mannan, M.A. (2014). Foliar and soil fertilization effect on seed yield and protein content of soybean. Bangladesh Agron. J. 17:67-72.

Mekki, B.B and Ahmed, A.G. (2005). Growth, yield and seed quality of soybean (Glycine max L.) as affected by organic, biofertilizer and yeast application. Research Journal of Agriculture and Biological Sciences 1:320-324.

Myint, T.Z. Sooksathan I. Kaveeta R and Juntakool S. (2009). Effects of different organic amendment and chemical fertilizer on plant growth and grain yield of soybean on Pakchong soil series. KasetsartJ.(Nat. Sci.) 43:432-441.

Olowe, V.I.O and Adebimpe, O.A. (2009). Intercropping sunflower with soybeans enhances total crop productivity. Biological Agriculture and Horticulture 26:365-377.

Olowe, V.I., Adejuyigbe, C, Oshundiya, F, Ajibde, O, Adeboye, O and Bakare, J. (2014). Agronomic performance of soybeans (Glycine max (L.) Merrill) in an organic crop rotation system. In Rahmann, G and Aksoy, U (eds). Proceedings of the $4^{\text {th }}$ ISOFAR Scientific Conference tagged "Building Organic Bridges" held on 13-15 Oct. 2014 in Istanbul, Turkey 835-837.

Prihastuti, Abidin Z and Sutrisno D.I. (2015). Evaluation of organic fertilizer application on soybean in the village ubaru, District Sumenep, Madura Island. International Journal of research in Agriculture and Forestry 2:27-34.

Yagoub, S.O, Ali Ahmed, W.M and Mariod, A.A (2012). Effect of urea, NPK and compost on growth and yield of soybean (Glycine max L.) in semi-arid region of Sudan. International Scholarly Research Network. Doi:10.5402/2012/678124.6p.

Yan D, Wang D. and Yang L. (2007). Long term effect of chemical fertilizer, straw and manure on liable organic matter fractions in a paddy soil. Biol Fert. Soils 44:93-101.

Zerihun, A and Haile D. (2017). The effect of organic and inorganic fertilizers on the yield of two contrasting soybean varieties and residual nutrient effects on a subsequent finger millet crop. Agronomy 7: 1-15.

Zong W, Gu T. Wang W, Zang B. Lin X Huang Q and Shen W. (2010). The effect of mineral fertilizer and organic manure on soil microbial community and diversity. Plant Soil 326: 511-522. 